\title{
Trace Element Determination in Sulfur Samples Using a Novel Digestion Bomb Prior to ICP-MS Analysis
}

\author{
Xuebo Yin ${ }^{a, c}$, Xiaoyuan Wang*,a,b,c, Shuai Chen ${ }^{\text {a,c }}$, Yao Ma ${ }^{\text {a,c }}$, Guo Kun ${ }^{\text {a,d }}$, and Zhigang Zeng,b,c \\ a Key Laboratory of Marine Geology and Environment, \\ Institute of Oceanology, Chinese Academy of Sciences, Qingdao 266071, P.R. China \\ b Laboratory for Marine Mineral Resources, \\ Qingdao National Laboratory for Marine Science and Technology, Qingdao 266071, P.R. China \\ c Center for Ocean-Mega Science, Chinese Academy of Sciences, Qingdao 266071, P.R. China \\ d College of Earth Science and Engineering, Shandong University of Science and Technology, \\ Qingdao 266590, P.R. China
}

\section{INTRODUCTION}

Trace elements play an important role in investigating the origin of sulfur in many geological systems such as hydrocarbon-bearing basins, near active or dormant volcanoes, or in seafloor hydrothermal settings (1-12), and provide microscale information on the metal transport via sulfur-rich volcanic degassing (13-16). In addition, the concentration of trace elements is significant to establish the quality of sulfur which is widely used in agriculture, medicine, synthetic rubber, building materials, powders, and the manufacture of petroleum and coal products, etc. (6).

Researchers have made great progress towards the accurate determination of trace elements in sulfur samples (15-18). Inductively coupled plasma mass spectrometry (ICP-MS) has become one of the most powerful techniques due to its high sensitivity, large dynamic linear range, and multi-element capabilities (19-30). The interference encountered in ICP-MS is reduced by using hydride generation, aerosol dilution after iron hydroxide co-precipitation, $\mathrm{Ar}-\mathrm{CH}_{4}$ or $\mathrm{CH}_{4}$ plasma, and analysis by dynamic reaction cell (DRC ${ }^{\mathrm{TM}}$ ) (19, $23,24,26-28)$. The analysis of trace elements in sulfur is challenging due to the difficulties in digestion and the high sulfur matrix in the final solution for ICP-MS analysis.

*Corresponding autbor.

E-mail: wangxiaoyuan@qdio.ac.cn

Fax: +86 - 532-82898526

\section{ABSTRACT}

A method has been developed for the ICP-MS determination of trace elements in sulfur samples using a novel closed digestion bomb with a double inner arc seal design. The method is simple, precise, and accurate, completely digests the sulfur sample, and allows for the determination of the trace elements $\mathrm{Ba}, \mathrm{Ce}, \mathrm{Cd}$, $\mathrm{Co}, \mathrm{Cr}, \mathrm{Cs}, \mathrm{Dy}, \mathrm{Er}, \mathrm{Eu}, \mathrm{Ga}, \mathrm{Gd}$, $\mathrm{Ho}, \mathrm{La}, \mathrm{Li}, \mathrm{Lu}, \mathrm{Nd}, \mathrm{Pb}, \mathrm{Pr}, \mathrm{Rb}, \mathrm{Sm}$, $\mathrm{Sr}, \mathrm{Tb}, \mathrm{Tm}, \mathrm{U}, \mathrm{V}, \mathrm{Y}$, and $\mathrm{Yb}$. Upon the addition of trace element standards to a high purity sulfur chemical reagent, the recoveries were $91.5 \%$ for La to $109.7 \%$ for $\mathrm{U}$. The detection limits of this method were $1.49 \mathrm{ng} \mathrm{g}^{-1}$ for Sr to $0.009 \mathrm{ng} \mathrm{g}^{-1}$ for Tm and Lu.

Burning and sublimation methods for the determination of trace elements in sulfur samples using ICP-MS has been proposed $(13,16-$ 18). Examples of such procedures require $1 \mathrm{~g}$ sulfur sample, heating to above $236^{\circ} \mathrm{C}$ (sulfur burning temperature) in a muffle furnace to eliminate sulfur as $\mathrm{SO}_{2}$ or heating the sample at $200{ }^{\circ} \mathrm{C}$ in a beaker on an electrothermal plate to vaporize the sulfur. The ashes or residues are then dissolved using $\mathrm{HNO}_{3}, \mathrm{HF}$, and $\mathrm{HClO}_{4}$. However, these methods can cause contamination and loss of volatile elements, particularly for sulfur samples with a very low abundance of trace elements. For geological samples, a high-pressure digestion technique (31-33) has been generally applied. Neverthe- less, acid leakage often occurs during the digestion process which may leave undissolved residues.

In this study, the traditional high pressure digestion technique has been improved by using a corrosive-resistant digestion bomb with a double inner arc seal design. The bomb has a tight seal and offers effective circulation of the acid during the digestion process. The sulfur sample can be digested directly at high temperature and pressure which speeds up the digestion process, improves the dissolution effect, and is a practical and simple sample digestion method for the analysis of sulfur samples by ICP-MS.

\section{EXPERIMENTAL}

\section{Instrumentation}

An ELAN ${ }^{\circledR}$ DRCII ICP-MS

(PerkinElmer, Inc., Shelton, CT, USA) was used for the sample analysis at the Institute of Oceanology, Chinese Academy of Sciences. The instrumental parameters used for the trace element determinations are listed in Table I. The detection isotopes were as follows: ${ }^{7} \mathrm{Li},{ }^{51} \mathrm{~V}$, ${ }^{52} \mathrm{Cr},{ }^{59} \mathrm{Co},{ }^{71} \mathrm{Ga},{ }^{85} \mathrm{Rb},{ }^{86} \mathrm{Sr},{ }^{89} \mathrm{Y}$, ${ }^{114} \mathrm{Cd},{ }^{133} \mathrm{Cs},{ }^{135} \mathrm{Ba},{ }^{208} \mathrm{~Pb},{ }^{238} \mathrm{U}$ and ${ }^{39} \mathrm{La},{ }^{140} \mathrm{Ce},{ }^{141} \mathrm{Pr},{ }^{146} \mathrm{Nd},{ }^{147} \mathrm{Sm}$, ${ }^{151} \mathrm{Eu},{ }^{160} \mathrm{Gd},{ }^{159} \mathrm{~Tb},{ }^{163} \mathrm{Dy},{ }^{165} \mathrm{Ho}$, ${ }^{166} \mathrm{Er},{ }^{169} \mathrm{Tm},{ }^{172} \mathrm{Yb}$, and ${ }^{175} \mathrm{Lu} .{ }^{187} \mathrm{Re}$ was used as an internal standard. The background counts for the $2 \% \mathrm{HNO}_{3}$ solutions were normally $<2$ cps.

\section{Reagents and Standards}

A $10-\mathrm{mg} \mathrm{L}^{-1}$ multi-element mixed standard solution and a $10-\mathrm{mg} \mathrm{L}^{-1}$ 
REE standard solution (PerkinElmer, Inc., Shelton, CT, USA) were used and diluted with $2 \% \mathrm{HNO}_{3}$ to $1 \mathrm{ng} \mathrm{mL}-1,5 \mathrm{ng} \mathrm{mL}^{-1}$, and $10 \mathrm{ng} \mathrm{mL}^{-1}$. A 1000-mg L ${ }^{-1}$ Re standard solution (Environmental Express, USA) was diluted to $10 \mu \mathrm{g} \mathrm{L}^{-1}$ with $2 \% \mathrm{HNO}_{3}$. A $1000 \mathrm{mg} \mathrm{L}^{-1} \mathrm{~S}$ standard solution (Environmental Express) was diluted to $100 \mathrm{mg} \mathrm{L}^{-1}$ with $2 \%$ $\mathrm{HNO}_{3}$. The reagents applied were ultrapure $\mathrm{HNO}_{3}$ (J. T. Baker, USA), electronic industry-grade $\mathrm{HF}$ and chemical reagent-grade sulfur (sulfur content $>99.5 \%$ ). Distilled water $(18.2 \mathrm{M} \Omega \cdot \mathrm{cm}$ grade) was obtained with an ULTRA IONIC ultrapure water system (ELGA, UK).

\section{Laboratory Ware}

A screw-top, PTFE-lined, corro-

\section{TABLE I}

Instrumental Operating Parameters for ICP-MS Analysis

\begin{tabular}{lr}
\hline Parameters & \multicolumn{1}{c}{ Values } \\
\hline RF power & $1250 \mathrm{~W}$ \\
Plasma gas & $15 \mathrm{~L} \mathrm{~min}^{-1}$ \\
Aux gas & $1.20 \mathrm{~L} \mathrm{~min}^{-1}$ \\
Nebulizer gas & $0.80 \mathrm{~L} \mathrm{~min}^{-1}$ \\
Sweeps & 10 \\
Readings & 1 \\
Replicates & 3 \\
Scan mode & $100 \mathrm{~ms}$ \\
Channel dwell time & $1.10 \mathrm{~mm}$ \\
per sweep & $0.90 \mathrm{~mm}$ \\
Sampling cone $(\mathrm{Pt})$ & \\
Skimmer cone $(\mathrm{Pt})$ &
\end{tabular}

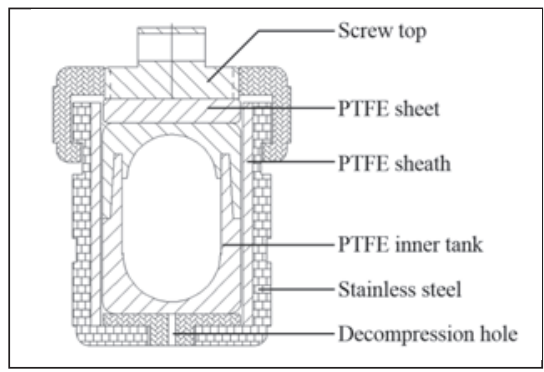

Fig. 1. Diagram showing the design of the anticorrosive efficient digestion bomb. sive-resistant digestion bomb (Figure 1) was used for this study with a volume of $\sim 15 \mathrm{~mL}$. The upper part of the inner tube plugs into the top of the lower part and the axial cross of the inner tube is oval. The inner tube was pre-cleaned with $10 \% \mathrm{HNO}_{3}$ and heated to boiling for about 12 hours at $120^{\circ} \mathrm{C}$ on an electrothermal plate, then rinsed with DI water.

\section{Sample Preparation}

The sulfur samples were first milled to 200 mesh with an agate mortar. Next, $0.0400 \mathrm{~g}$ of the sample powder was digested using $0.5 \mathrm{~mL} \mathrm{HNO}_{3}, 0.1 \mathrm{~mL} \mathrm{HF}$, and $4 \mathrm{~mL}$ DI water, then heated at $180^{\circ} \mathrm{C}$ for 12 hours. After cooling, the PTFE inner tank was placed on an electrothermal plate and heated to dryness at $150{ }^{\circ} \mathrm{C}$, then $0.2 \mathrm{~mL}$ of $\mathrm{HNO}_{3}$ was added, and heated to dryness again. To this residue, $1.5 \mathrm{~mL}$ of $2 \% \mathrm{HNO}_{3}$ was added, the high pressure bomb was sealed, and the contents were dissolved again at $150{ }^{\circ} \mathrm{C}$ for 12 hours. Finally, the solutions were diluted 50 times using $2 \% \mathrm{HNO}_{3}$ and analyzed by ICP-MS.

\section{RESULTS AND DISCUSSION}

\section{Calibration Curves and Limits of Detection}

Before determination, the ICPMS instrument was optimized using a tuning solution containing $1 \mathrm{ng}$ $\mathrm{mL}^{-1}$ of $\mathrm{Be}, \mathrm{Co}, \mathrm{In}, \mathrm{Mg}, \mathrm{Ce}, \mathrm{Pb}$, and $\mathrm{U}$, and $10 \mathrm{ng} \mathrm{mL}^{-1}$ of $\mathrm{Ba}$, then calibrated using three synthetic trace element standard solutions of $1 \mathrm{ng}$ $\mathrm{mL}^{-1}, 5 \mathrm{ng} \mathrm{mL} L^{-1}$, and $10 \mathrm{ng} \mathrm{mL}^{-1}$ in $2 \% \mathrm{HNO}_{3}$. A Re internal standard (10 $\mathrm{ng} \mathrm{mL}^{-1}$ ) was added on-line using a polypropylene T-connector. The detection limit was calculated as three times the standard deviation of 10 individual procedural reagent blanks, divided by the sample mass. The limits of detection

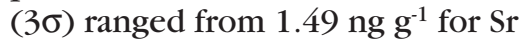
to $0.009 \mathrm{ng} \mathrm{g}^{-1}$ for Tm and $\mathrm{Lu}$ for a sample of $0.0400 \mathrm{~g}$ prepared into a 2-mL analytical solution, i.e., a dilution factor of 50 (Table II).

\section{Interference and Correction}

Combining the methods of sulfur oxidation into stable sulfate using a mixed acid $(34,35)$ and the previously described high pressure digestion technique (31-33), the sulfur samples were dissolved with the mixed acid at high pressure in a custom-designed digestion bomb (built in this laboratory) into a clear liquid. The sulfur content in the solutions before ICP-MS determination was $873-883 \mathrm{mg} \mathrm{L}^{-1}$ as analyzed using ICP-OES (Thermo IRIS Intrepid II XSP) and thus, interference from sulfur has to be considered. Sulfur has four stable isotopes at nominal masses of 32, 33, 34, and 36 , with a representative isotopic composition of $94.99,0.75$, 4.25 , and $0.01 \%$, respectively (36). Most spectral interferences arise from the sulfur, oxygen, and argon polyatomics. The mass spectra for the $100 \mathrm{mg} \mathrm{L}^{-1}$ sulfur standard solution indicates significant interferences for ${ }^{48} \mathrm{Ti}$ (interference by ${ }^{32} \mathrm{~S}^{16} \mathrm{O}$ ), ${ }^{64} \mathrm{Zn}$ (interference by ${ }^{32} \mathrm{~S}_{2}$, ${ }^{32} \mathrm{~S}^{16} \mathrm{O}_{2}$ ), ${ }^{65} \mathrm{Cu}$ (interference by ${ }^{32} \mathrm{~S}^{33} \mathrm{~S}$ and ${ }^{33} \mathrm{~S}^{16} \mathrm{O}_{2}$ ), ${ }^{66} \mathrm{Zn}$ (interference by ${ }^{32} \mathrm{~S}^{16} \mathrm{O}^{18} \mathrm{O},{ }^{32} \mathrm{~S}^{34} \mathrm{~S}$ and ${ }^{33} \mathrm{~S}_{2}$ ), and ${ }^{72} \mathrm{Ge}$ (interference by ${ }^{36} \mathrm{~S}_{2}$ and ${ }^{32} \mathrm{~S}^{40} \mathrm{Ar}$ ) (Figure 2). The interference coefficient correction method does not reduce or eliminate the interferences, therefore, the concentration of $\mathrm{Ti}, \mathrm{Zn}, \mathrm{Cu}$, and $\mathrm{Ge}$ in the sulfur sample cannot be determined accurately using the proposed method. During the analysis of the sulfur sample, the interference of the Baoxides on the REEs was significant, i.e., of ${ }^{136} \mathrm{Ba}^{16} \mathrm{O}$ on ${ }^{152} \mathrm{Sm},{ }^{135} \mathrm{Ba}^{16} \mathrm{O}$ on ${ }^{151} \mathrm{Eu}$, and ${ }^{137} \mathrm{Ba}^{16} \mathrm{O}$ on ${ }^{153} \mathrm{Eu}$. ${ }^{147} \mathrm{Sm}$ was selected to be analyzed, thus avoiding the interference of ${ }^{136} \mathrm{Ba}^{16} \mathrm{O}$. The $\mathrm{BaO}^{+} / \mathrm{Ba}^{+}$ratio (1.936\%) obtained by the determination of a 10-mg L $\mathrm{m}^{-1}$ Ba standard solution and the correction formula $\left({ }^{151} \mathrm{Eu}_{\text {true }}=\right.$ $\left.{ }^{151} \mathrm{Eu}_{\text {analyzed }}-0.001936 \times{ }^{135} \mathrm{Ba}\right)$ were 
TABLE II

Blank Level (ng $\mathbf{~ g}^{-1}$ ) and Method's Limit of Detection (ng $\mathbf{~ g}^{-1}$ )

\begin{tabular}{|c|c|c|c|c|c|c|}
\hline Elements & Blank-1 & Blank-2 & Blank-3 & Blank-4 & Average & $\operatorname{DL}(3 \sigma)$ \\
\hline $\mathrm{Li}$ & 0.75 & 0.74 & 0.87 & 0.80 & 0.79 & 0.18 \\
\hline V & 2.06 & 2.06 & 1.66 & 2.14 & 1.98 & 0.66 \\
\hline $\mathrm{Cr}$ & 1.34 & 1.54 & 1.28 & 1.13 & 1.32 & 0.51 \\
\hline Co & 0.41 & 0.33 & 0.48 & 0.32 & 0.38 & 0.22 \\
\hline $\mathrm{Ga}$ & 0.29 & 0.26 & 0.34 & 0.22 & 0.28 & 0.15 \\
\hline $\mathrm{Rb}$ & 0.33 & 0.13 & 0.14 & 0.21 & 0.20 & 0.28 \\
\hline $\mathrm{Sr}$ & 3.31 & 2.41 & 2.24 & 2.33 & 2.57 & 1.49 \\
\hline $\mathrm{Cd}$ & 0.045 & 0.044 & 0.036 & 0.047 & 0.043 & 0.015 \\
\hline Cs & 0.023 & 0.017 & 0.015 & 0.011 & 0.016 & 0.014 \\
\hline $\mathrm{Ba}$ & 2.42 & 2.62 & 2.45 & 2.20 & 2.42 & 0.64 \\
\hline $\mathrm{Pb}$ & 2.40 & 2.49 & 2.14 & 2.45 & 2.37 & 0.47 \\
\hline $\mathrm{U}$ & 0.81 & 0.78 & 0.73 & 0.80 & 0.78 & 0.11 \\
\hline $\mathrm{La}$ & 0.32 & 0.26 & 0.28 & 0.30 & 0.29 & 0.080 \\
\hline $\mathrm{Ce}$ & 0.53 & 0.60 & 0.51 & 0.58 & 0.55 & 0.13 \\
\hline $\operatorname{Pr}$ & 0.066 & 0.053 & 0.05 & 0.056 & 0.056 & 0.021 \\
\hline $\mathrm{Nd}$ & 0.23 & 0.21 & 0.28 & 0.17 & 0.22 & 0.14 \\
\hline $\mathrm{Sm}$ & 0.048 & 0.019 & 0.048 & 0.035 & 0.038 & 0.042 \\
\hline $\mathrm{Eu}$ & 0.029 & 0.018 & 0.023 & 0.015 & 0.021 & 0.019 \\
\hline Gd & 0.050 & 0.035 & 0.032 & 0.038 & 0.039 & 0.024 \\
\hline $\mathrm{Tb}$ & 0.010 & 0.007 & 0.016 & 0.005 & 0.010 & 0.015 \\
\hline Dy & 0.035 & 0.017 & 0.060 & 0.016 & 0.032 & 0.062 \\
\hline Ho & 0.010 & 0.005 & 0.013 & 0.005 & 0.008 & 0.011 \\
\hline $\mathrm{Er}$ & 0.023 & 0.012 & 0.030 & 0.013 & 0.020 & 0.026 \\
\hline $\mathrm{Tm}$ & 0.012 & 0.007 & 0.012 & 0.007 & 0.010 & 0.009 \\
\hline $\mathrm{Yb}$ & 0.029 & 0.017 & 0.047 & 0.010 & 0.026 & 0.048 \\
\hline $\mathrm{Lu}$ & 0.015 & 0.012 & 0.016 & 0.009 & 0.013 & 0.009 \\
\hline $\mathrm{Y}$ & 0.18 & 0.12 & 0.17 & 0.11 & 0.15 & 0.10 \\
\hline
\end{tabular}

used to correct the interference of the Ba-oxides on $\mathrm{Eu}$. In addition, ${ }^{71} \mathrm{Ga}$ was selected to be analyzed, thus avoiding the interference of ${ }^{138} \mathrm{Ba}^{++}$.

\section{Method Efficiency}

The advantages of the corrosiveresistant digestion bomb (Figure 1) are its double inner arc seal design which allows the evaporating acid to return from the top of the inner tank to the bottom without clinging on the tank wall, thus providing an effective circulation. The upper and lower parts of the inner tank couple tightly and the double inner arc seal design ensures a tight seal as the pressure increases. This prevents any leaking of the acid and avoids incomplete digestion. In comparison to previously reported methods that pretreat the native sulfur samples and require $4-6$ days $(13,16$, $17,18)$, the present method requires 24 hours with no contamination problems, consumes a small amount of sample $(40 \mathrm{mg})$ and acid $\left(0.7 \mathrm{~mL}\right.$ of $\mathrm{HNO}_{3}$ and $0.1 \mathrm{~mL}$ of $\mathrm{HF}$ ), and has good precision and accuracy. In addition, 27 elements can be measured at the same time with high accuracy (Table III).

\section{Procedural Recovery and Precision}

Lacking a native sulfur reference material, the recovery was used to

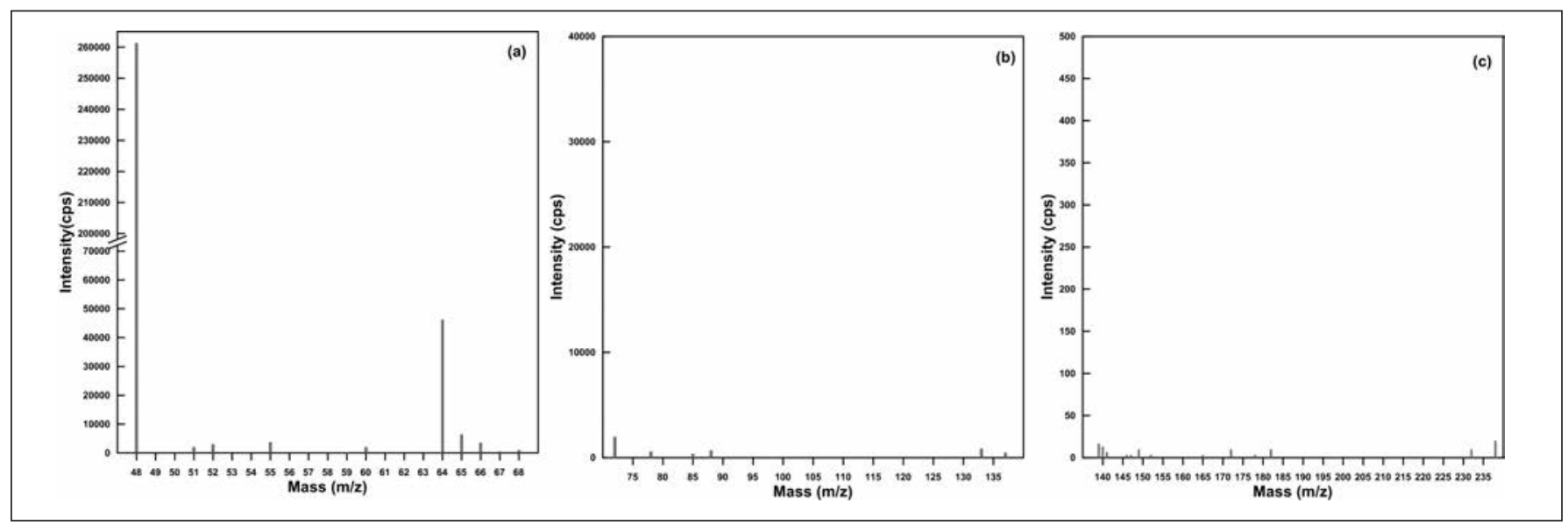

Fig. 2. The mass spectra recorded for a 100-mg $\mathrm{L}^{-1}$ sulfur standard solution using ICP-MS 
validate the accuracy of this method. In order to evaluate analyte recovery, $50 \mathrm{ng} \mathrm{g}^{-1}$ trace element standards and $2.5 \mathrm{ng} \mathrm{g}^{-1} \mathrm{REE}$ standards were added to $40 \mathrm{mg}$ of the unknown samples, and the samples were prepared as described above and analyzed. The samples were digested completely, and the digestion solution was clear without any undissolved substances. The added concentrations were obtained by subtracting the concentrations of the sample with free trace element standards from the corresponding sample with the addition of trace element standards. The recovery varied from $91.5 \%$ (La) to $109.7 \%(\mathrm{U})$ for the sulfur sample (Table III). The recovery of this method was found to be much better than for the burning and sublimation methods (Table III). The data obtained in the present study show reasonable precision, better than $6.2 \%$ for trace elements and $5 \%$ for the REEs and is, therefore, suitable for the analysis of sulfur samples.

\section{CONCLUSION}

The proposed method for the analysis of sufur samples is novel and has some important advantages when compared to previously reported analytical techniques. An anti-corrosive, lab-made efficient digestion bomb was used which required a dilution factor of only 50 for the preparation of the analytical solutions. The method is reliable, simple, has no contamination problems, is fast ( 24 hours in comparison to 4 to 6 days with other methods), with a precision $0.5 \%$ for $\mathrm{Ba}$ to $6.2 \%$ for $\mathrm{Ga}$, and is suitable for the routine determination of most trace elements found in sulfur samples.

\section{ACKNOWLEDGMENTS}

The authors wish to thank International Science Editing (http://www.internationalscience editing.com) for editing this manu-

TABLE III

Trace Element Recoveries and Relative Standard Deviation ${ }^{\text {a }}$

\begin{tabular}{|c|c|c|c|c|c|c|}
\hline Element & $\begin{array}{c}\text { Sulfur } \\
(n=5)\end{array}$ & $\begin{array}{r}\text { RSD } \\
(\%)\end{array}$ & $\begin{array}{l}\text { Sulfur Sample With } \\
\text { Added Standard } \\
\text { Solution } \\
(n=5)\end{array}$ & $\begin{array}{l}\text { Recovery } \\
\text { (\%) }\end{array}$ & $\begin{array}{l}\text { Recovery } \\
\text { (\%) } \\
\text { Sublimation } \\
\text { Method }^{\text {beth }}\end{array}$ & $\begin{array}{c}\text { Recovery } \\
\text { (\%) } \\
\text { Burning } \\
\text { Method }\end{array}$ \\
\hline $\mathrm{Li}$ & 7.34 & 3.1 & 57.3 & 100.0 & - & - \\
\hline V & 37.1 & 1.5 & 87.6 & 101.0 & 89.0 & - \\
\hline $\mathrm{Cr}$ & 94.7 & 5.8 & 144 & 99.5 & - & - \\
\hline Co & 5.30 & 3.7 & 58.7 & 106.9 & 88.4 & 78.3 \\
\hline $\mathrm{Ga}$ & 3.15 & 6.2 & 51.0 & 95.7 & 107.1 & 86.5 \\
\hline $\mathrm{Rb}$ & 5.19 & 6.0 & 51.9 & 93.5 & 84.9 & - \\
\hline $\mathrm{Sr}$ & 55.9 & 3.0 & 106 & 105.9 & - & - \\
\hline $\mathrm{Cd}$ & 3.06 & 1.4 & 54.0 & 101.9 & - & - \\
\hline Cs & 0.31 & 0.9 & 54.3 & 107.9 & 118.6 & 76.2 \\
\hline $\mathrm{Ba}$ & 336 & 0.5 & 386 & 100.0 & - & - \\
\hline $\mathrm{Pb}$ & 603 & 2.1 & 657 & 107.2 & - & - \\
\hline $\mathrm{U}$ & 4.40 & 2.4 & 59.2 & 109.7 & 97.1 & 90.2 \\
\hline $\mathrm{La}$ & 5.74 & 2.9 & 8.02 & 91.5 & 91.4 & - \\
\hline $\mathrm{Ce}$ & 11.5 & 2.1 & 13.9 & 97.3 & - & - \\
\hline $\mathrm{Pr}$ & 1.39 & 2.1 & 4.05 & 106.5 & 92.2 & - \\
\hline $\mathrm{Nd}$ & 5.54 & 4.7 & 7.93 & 95.9 & 90.3 & - \\
\hline $\mathrm{Sm}$ & 1.20 & 4.9 & 3.57 & 94.9 & 129.2 & 91.5 \\
\hline $\mathrm{Eu}$ & 0.24 & 4.4 & 2.84 & 104.0 & 101.7 & 96.1 \\
\hline Gd & 0.84 & 3.5 & 3.45 & 104.4 & 97.4 & - \\
\hline $\mathrm{Tb}$ & 0.14 & 3.2 & 2.61 & 98.6 & 104.8 & 86.5 \\
\hline Dy & 0.76 & 2.5 & 3.41 & 106.0 & 110.7 & 91.2 \\
\hline Ho & 0.15 & 1.9 & 2.71 & 102.5 & 101.5 & 95.1 \\
\hline $\mathrm{Er}$ & 0.42 & 3.3 & 2.98 & 102.2 & 108.1 & 98.0 \\
\hline $\mathrm{Tm}$ & 0.07 & 3.8 & 2.65 & 103.1 & 98.6 & 92.7 \\
\hline $\mathrm{Yb}$ & 0.40 & 3.3 & 3.01 & 104.1 & 97.2 & 92.6 \\
\hline $\mathrm{Lu}$ & 0.07 & 4.3 & 2.62 & 102.2 & 98.5 & 92.1 \\
\hline $\mathrm{Y}$ & 2.81 & 4.3 & 5.37 & 102.7 & 115.0 & 92.4 \\
\hline
\end{tabular}

${ }^{a}$ Data in $\mathrm{ng} \mathrm{g}^{-1}$.

${ }^{\mathrm{b}}$ Data from References 17 and 18.

script. This research was supported by the National Natural Science Foundation of China (Grant No. 41476044, 41706052), the International Partnership Program of Chinese Academy of Sciences (Grant No. 133137KYSB20170003), the Special Fund for the Taishan Scholar Program of Shandong Province (Grant No. ts201511061), and AoShan Talents Program Supported by Qingdao National Laboratory for Marine Science and
Technology (Grant No. 2015ASTP0S17).

\section{REFERENCES}

1. S.Z. Jassim, R. Raiswell, and S.H. Bottrell, J. Geol. Soc. London 156, 25 (1999).

2. A. Ueda, H. Sakai, and A. Sasaki, Geochem. J. 13, 269 (1979).

3. C. Oppenheimer and D. Stevenson, Nature 342, 790 (1989).

4. P. Delmelle and A. Bernard, 
Geochim. Cosmochim. Acta 58, 2445 (1994).

5. B. Takano, H. Saitoh, and E. Takano, Geochem. J. 28, 199 (1994).

6. C. W. Mandeville, Elements 6, 75 (2010).

7. M. Piochi, A. Mormone, G. Balassone, H. Strauss, C. Troise, and G. De Natale, J. Volcanol. Geoth. Res. 304, 180 (2015).

8. K. Iizasa, R. S. Fiske, O. Ishizuka, M. Yuasa, J. Hashimoto, J. Ishibashi, J. Naka, Y. Horii, Y. Fujiwara, A. Imai, and S. Koyama, Science 283, 975 (1999).

9. C. E. J. de Ronde, E. T. Baker, G. J. Massoth, J. E. Lupton, I. C. Wright, R. A. Feely, and R. R. Greene, Earth Planet Sc. Lett. 193, 359 (2001).

10. C.T.A. Chen, Z. G. Zeng, F. W. Kuo, T. F. Yang, B. J. Wang, and Y. Y. Tu, Chem. Geol. 224, 69 (2005).

11. R. W. Embley, E. T. Baker, D. A. Butterfield, W. W. Chadwick, J. E. Lupton, J. A. Resing, C. E. J. de Ronde, K. Nakamura, V. Unnicliffe, J. F. Dower, and S. G. Merle, Oceanography 20, 68 (2007).

12. J. W. Park, I. H. Campbell, and J. Kim, Geochim. Cosmochim. acta 174, 236 (2016).

13. Z. G. Zeng, C. H. Liu, C. T. A. Chen, X. B. Yin, D. G. Chen, X. Y. Wang, X. M. Wang, and G. L. Zhang, Sci. China Earth Sci. 50, 1746 (2007).

14. Z. Zajacz and W. Halter, Earth Planet Sc. Lett. 282, 115 (2009).

15. J. Kim, K. Y. Lee, and J. H. Kim, Geology 39, 351 (2011).

16. Z. G. Zeng, C. T. A. Chen, X. Y. Zhang, X. Y. Wang, G. L. Zhang, X. M. Wang, and D. G. Chen, J. Asian Earth Sci. 40, 661 (2011).

17. C. H. Liu, X. B. Yin, X. Y. Wang, C. W. Yuan, and S. X. Yu, Marine Sciences, 30, 1 (2006). (In Chinese)

18. C. H. Liu, X. M. Wang, X. B. Yin, C. W. Yuan, and C. H. Zhang, Journal of Oceanography in Taiwan Strait, 26, 596 (2007). (In Chinese)

19. M.C. Saha, R. Baskey, S. Lahiri, and S. Dutta, At. Spectrosc. 38(1), 7 (2017).

20. W. Guo, L.L. Jin, S.H. Hu, and Q.H. Guo, J. Agri. Food Chem. 65, 3406
(2017).

21. D.Y. Tao, W. Guo, W.K. Xie, L.L. Jin, Q.H. Guo, and S.H. Hu., Microchem. J. 135, 221 (2017).

22. W. Guo, Z.W. Wu, S.H. Hu, L.L. Jin, K.Y. Qiu, and Q.H. Guo, Rsc. Adv. 6, 47394 (2016).

23. Y.T. Li, W. Guo, A.K. Souders, L.L. Jin, Y.Q. Ke, Q.H. Guo, and S.H. Hu, Rsc. Adv. 6, 108247 (2016).

24. Y.T. Li, W. Guo, Z.W. Wu, L.L. Jin, Y.Q. Ke, Q.H. Guo, and S.H. Hu, Microchem. J. 126, 194 (2016).

25. Y.E. Peng, W. Guo, J. Zhang, Q. H. Guo, L. L. Jin, and S. H. Hu, Microchem. J. 124, 127 (2016).

26. W. Guo, Y. X. Wang, J. X. Li, Y. E. Peng, L. L. Jin, Q. H. Guo, and S. H Hu, Atom. Spectrosc. 37, 7 (2016).

27. W. Guo, W.K. Xie, L.L. Jin, Q. H. Guo, and S. H. Hu, Rsc. Adv. 5, 103189 (2015).

28. W. Guo, S.H. Hu, Z.W. Wu, G.Y. Lan, L.L. Jin, X.G. Pang, J.C. Zhan, B. Chen, and Z.Y. Tang, J. Anal. At. Spectrom. 30, 986 (2015).

29. Q. Xu, W. Guo, L.L. Jin, Q.H. Guo, and S.H. Hu, J. Anal. At. Spectrom. 30, 2010 (2015).

30. B. Zawisza, K. Pytlakowska, B. Feist, M. Polowniak,A. Kita, and R. Sitko, J. Anal. At. Spectrom. 26, 2373 (2011).

31. L. Qi, J. Hu, and D. C. Gregoire. Talanta 51, 507 (2000).

32. W. Diegor, H. Longerich, T. Abrajano, and I. Horn, Anal. Chim. Acta. 431, 195 (2001).

33. L. Qi, J. F. Gao, X. W. Huang, J. Hu, M. F. Zhou, and H. Zhong, J. Anal. At. Spectrom. 26, 1900 (2011).

34. L. Ackerman, J. Rohovec, and O. Šebek, Geostand. Geoanal. Res. 36, 407 (2012).

35. M. F. Gazulla, M. P. Gómez, M. Orduña, and M. Rodrigo, X-Ray Spectrom. 38, 3 (2009).

36. J. Giner Martínez-Sierra, O. Galilea San Blas, J.M. Marchante Gayón, and J.I. García Alonso, Spectrochim. Acta B 108, 35 (2015).

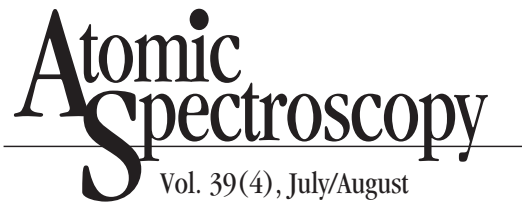

